\title{
Enterectomy, vagal deafferentation and nutrient utilization in the pig
}

\author{
J.P. LAPLACE \\ with the technical assistance of G. Duchastel, J.P. Hautducoevr and R. Levrel \\ I.N.R.A., Laboratoire de Physiologie de la Nutrition \\ Centre de Recherches zootechniques, F 78350 Jouy-en-Josas
}

\begin{abstract}
Summary
A nutritional balance study was conducted with 36 pair fed pigs to assess the digestive and metabolic utilization of food in pigs submitted either to a total vagal deafferentation, or to a $4 \mathrm{~m}$ distal jejunectomy, or to both deafferentation and jejunectomy, as compared to unoperated controls. The results recorded between the 18th and 28th post operative days failed to evidence any change except for a small but significant decrease of the metabolisable energy as per cent of digestible energy. This effect appeared as a non specific consequence of surgery whatever the operation performed.
\end{abstract}

\section{1. - Introduction}

A role of the sensory informations conveyed to the central nervous system through the vagal afferent pathways was recently evidenced in the compensation for the intestinal tissue loss after enterectomy as well as in the current regulation of the intestinal tissue mass (LAPLACE, $1980 \mathrm{a}$ and 1981). These results were obtained in the Pig using vagal deafferentation (LAPLACE, 1980 b) i.e. the surgical suppression of the vagal afferent (sensory) pathways originating below the diaphragm. However, vagal deafferentation results in severe gastric motor disturbances with a delayed gastric emptying (Darcy et al., 1979 - Laplace, Cuber \& Villiers, 1979 - LAPLACE, $1980 \mathrm{~b}$ ). Due to that, the effects of deafferentation, alone or in combination with partial enterectomy, might have been somewhat misinterpreted if these disorders result in a change of digestive and metabolic utilization of food. A nutritional balance study conducted in pigs allowed to discard this suspicion.

\section{2. - Material and methods}

Thirty-six castrated male pigs were cage housed. After habituation, they were randomly allotted to four experimental groups ( 9 pigs per group), at $30.27 \pm 0.21 \mathrm{~kg}$ 
mean ( \pm SEM) live weight and $93.3 \pm 1.3$ days of age. At this stage, surgery was performed under halothane anesthesia, according to the group as follows:

- Controls : unoperated pigs.

- Deafferented : pigs submitted to total deafferentation as previously described (LAPLACE, $1980 \mathrm{~b}$ ), the left nodose ganglion being resected in all cases.

- Resected : pigs submitted to a distal $4 \mathrm{~m}$ jejunectomy (LAPLACE, $1980 \mathrm{a}$ ), $120 \mathrm{~cm}$ above the ileo caecal junction, thus leaving in situ 68 per cent of the full small intestine length.

- Resected + deafferented : pigs submitted to both the jejunectomy and the total deafferentation as above.

After 24 hrs post operative starvation (in controls too), pigs were fed 3 times a day one part meal with two parts water added (on a weight basis), and received additional water ad libitum. The feed constituents were (as per cent) : barley 34.8, wheat 15.0 , maize 15.0 , wheat bran 10.0 , soya bean meal 18.0, minerals premix 3.0, vitamins premix 4.0, antibiotics 0.2 . The mean dietary contents were : dry matter (D.M.) 88.68 per cent, organic matter 93.39 per cent of D.M., nitrogen 3.02 per cent of D.M., and gross energy $4322.5 \mathrm{kcal} . \mathrm{kg}^{-1}$ D.M. (or 18.07 kjoules . $\mathrm{kg}^{-1}$ D.M.).

The whole experiment lasted 28 days, including 11 days for recovery with progressive refeeding (in controls too), 7 days to settle a common pair feeding level for the 36 pigs, and 10 days assigned to the nutritional balance study, maintaining this common pair feeding level at a constant rate.

During the last ten days period, urine and faeces were collected daily according to a standard procedure (Henry \& RERAT, 1966). Ash (incineration at $550{ }^{\circ} \mathrm{C}$ ), nitrogen (Kjeldahl method), energy (adiabatic calorimeter) and dry matter (oven drying at $105^{\circ} \mathrm{C}$ ) were determined on both samples of the diet and aliquots of homogenized faeces. Nitrogen and energy were measured in urines after lyophilisation. The true quantities of dry matter, organic matter, nitrogen and energy ingested, and excreted in the faeces, as well as the quantities of nitrogen and energy excreted in the urine, were determined. That allowed to calculate the various apparent digestibility coefficients, the nitrogen retention and the metabolizable to digestible energy ratio $(\mathrm{ME} / \mathrm{DE})$.

All the results were compared using both variance analysis (to test the effect of the pig and the effect of the experimental treatment) and bilateral Student's $t$ tests.

\section{3. - Results}

The growth and food intake of pigs over the whole 28 days period are given in table 1 . The mean initial live weight of pigs did not significantly differ in all the four groups. The mean daily true dry matter intake was closely similar, and despite the lower $(p<0.10)$ daily live weight gain in resected + deafferented pigs, the final live weights did not differ significantly (i.e. $43.74 \pm 0.35 \mathrm{~kg}$ as a mean for the 36 pigs). 


\section{TABLE 1}

Mean values ( $\pm S E M)$ of the performances of the pigs over the whole 28 days period The values indiced by different letters are significantly different according to a Student's $t$ test

Moyennes et écarts-types des performances des porcs pendant la période totale de 28 jours Les valeurs affectées par des lettres différentes diffèrent significativement selon le test $t$ de Student

\begin{tabular}{|c|c|c|c|c|}
\hline $\begin{array}{l}\text { Experimental groups } \\
\text { (9 pigs per group) }\end{array}$ & Controls & Deafferented & Resected & $\begin{array}{l}\text { Resected and } \\
\text { Deafferented }\end{array}$ \\
\hline $\begin{array}{c}\text { Initial live weight }(\mathrm{kg}) \text { at } \\
\text { surgery } \ldots \ldots \ldots \ldots \ldots\end{array}$ & $\begin{aligned} & 29.8 \mathrm{a} \\
\pm & 0.4\end{aligned}$ & $\pm 0.3^{30.5_{a}}$ & $\pm 0.5^{30.1_{\mathrm{a}}}$ & $\begin{aligned} & 30.7_{\mathrm{a}} \\
\pm & 0.4\end{aligned}$ \\
\hline $\begin{array}{l}\text { Dally dry matter intake (g) } \\
\text { over } 28 \text { days } \ldots \ldots \ldots\end{array}$ & $\begin{aligned} & 1051_{a} \\
\pm & 3\end{aligned}$ & $\begin{aligned} & 1031_{a} \\
\pm & 28\end{aligned}$ & $\pm 5^{1047_{\mathrm{a}}}$ & $\begin{array}{l}1011_{a} \\
\pm 26\end{array}$ \\
\hline $\begin{array}{l}\text { Daily live weight gain (g) } \\
\text { over } 28 \text { days } \ldots \ldots \ldots \\
\text { Final live weight }(\mathrm{kg}) \text { after }\end{array}$ & $\begin{aligned} & 504.8 \\
\pm & 17.4\end{aligned}$ & $\begin{aligned} & 493.6_{\mathrm{ab}} \\
\pm & 14.4\end{aligned}$ & $\begin{aligned} & 484.1_{\mathrm{ab}} \\
\pm & 14.6\end{aligned}$ & $\begin{aligned} & 442.1_{b} \\
\pm & 27.6\end{aligned}$ \\
\hline 2.8 days $\ldots \ldots \ldots \ldots$ & $\begin{aligned} & 43.9 \\
\pm & 0.7\end{aligned}$ & $\pm 0.7^{44.3 \mathrm{a}}$ & $\pm 0.8^{43.6_{a}}$ & $\begin{array}{l}43.1_{\mathrm{a}} \\
\pm 0.7^{2}\end{array}$ \\
\hline
\end{tabular}

During the nutritional balance study ( $18^{\text {th }}$ to $28^{\text {th }}$ day after surgery), the adequacy of pair feeding was verified, and the corresponding daily live weight gain did not differ between groups (table 2). The digestive utilization of the diet was quite similar, whatever the experimental treatment, as the apparent digestibility coefficients for dry matter, organic matter, nitrogen and energy, failed to differ anywise (table 2). As regards the metabolic utilization of the diet (table 2), the nitrogen retention and the net protein utilization did not differ significantly. But the experimental treatment significantly affected ( $\mathrm{F}: 5.84, \mathrm{p}<0.01$ ) the $\mathrm{ME} / \mathrm{DE}$ ratio. According to bilateral tests, it was reduced in the deafferented $(\mathrm{p}<0.01)$, resected $(\mathrm{p}<0.05)$ and resected + deafferented $(\mathrm{p}<0.001)$ pigs as compared to controls. As a matter of fact, the total urinary losses (table 2) of nitrogen did not differ significantly between groups, while energy excreted in the urines was increased in deafferented $(p<0.05)$, resected $(\mathrm{p}<0.10)$ and resected + deafferented $(\mathrm{p}<0.01)$ pigs. However, when expressed as Kcal per $\mathrm{g}$ nitrogen, the energy losses in the urines were increased in the 3 groups of operated pigs as compared to controls, but they were also significantly higher in deafferented $(\mathrm{p}<0.10)$ and resected + deafferented $(\mathrm{p}<0.05)$ pigs than in the resected pigs.

\section{4. - Discussion}

In agreement with previous observations (LAPLACE, 1970-1976) the apparent digestibility coefficients were not modified, and there was no significant change of the nitrogen retention coefficient nor of the net protein utilization after enterectomy. 


\section{TABLE 2}

Mean values ( $\pm S E M)$ of the performances of the pigs and of their digestive and metabolic utilization of the diet during the 18th to 28th post operative days

The values indiced by different letters are significantly different according to a Student's $t$ test

Moyennes et écarts-types des performances des porcs et de l'utilisation digestive et métabolique du régime pendant la période entre les $18^{\circ}$ et $28^{\circ}$ jours post-opératoires Les valeurs portant des lettres différentes diffèrent significativement

selon le test $t$ de Student

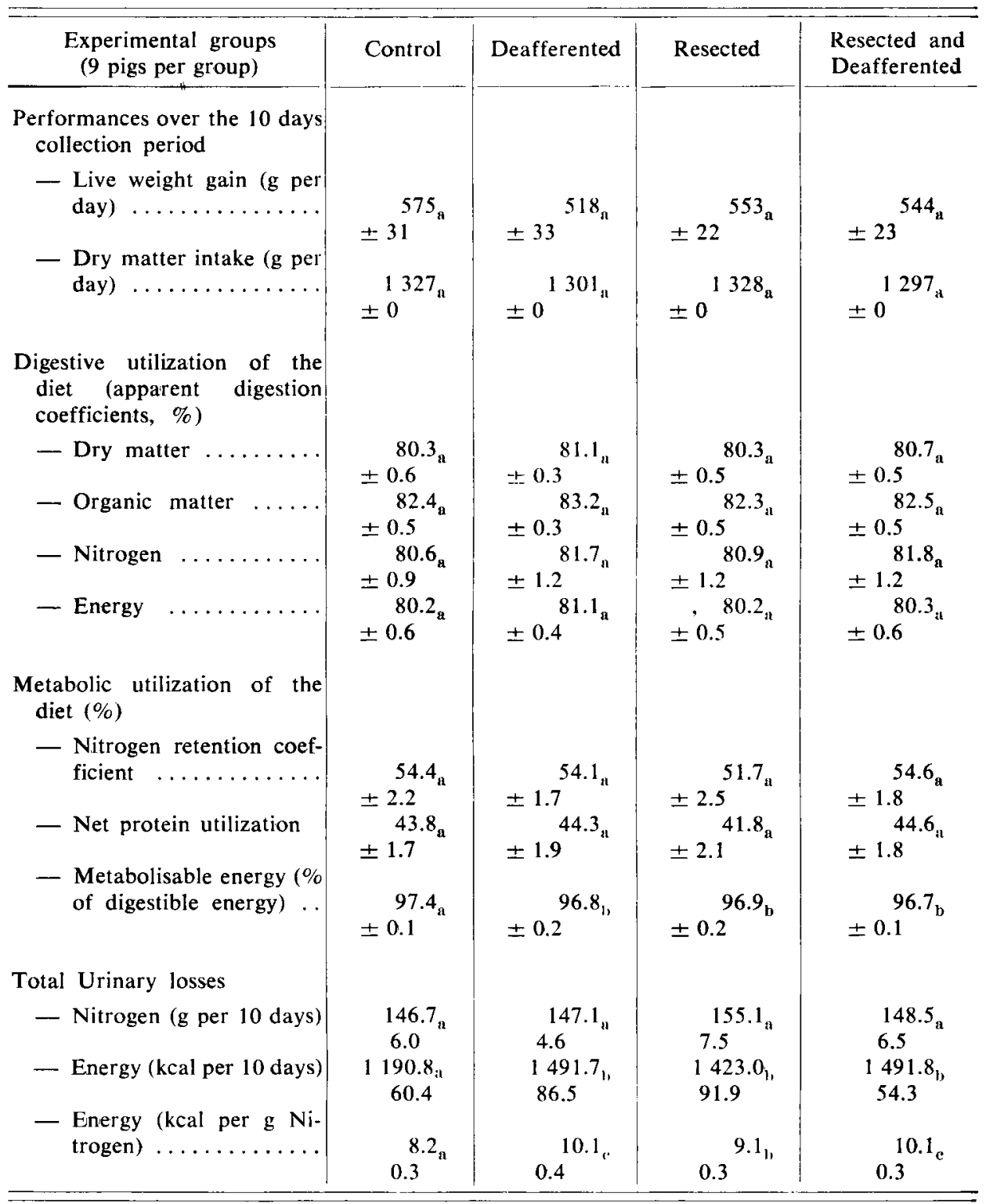


However one can notice that the nitrogen retention was somewhat improved in the previous experiments, while some decrease was recorded in the present experiment together with a definite but unsignificant increase of the nitrogen excretion in the urines. A significant decrease of the $\mathrm{ME} / \mathrm{DE}$ ratio was recorded between the $18^{\text {th }}$ and $28^{\text {th }}$ days after enterectomy, in association with a significant increase of the energy losses in the urines. A decrease of the $\mathrm{ME} / \mathrm{DE}$ ratio was also recorded in a previous experiment (LAPLACE, 1976), but it was significant only between the 67th and 76th post-operative days, i.e. much later than in the present case. Let's note however that the pair feeding level was higher in the previous experiment (LAPLACE, 1976) only including controls and resected pigs, i.e. 1576 g D.M. per day as compared to $1301 \mathrm{~g}$ D.M. per day in this experiment.

The effects recorded after total vagal deafferentation, performed alone, were quite the same as after enterectomy alone, that is only a reduced ME/DE ratio associated with increased losses of energy in the urines without any change of urinary nitrogen. The same was true after total deafferentation combined with enterectomy, without any additive effect on the ME/DE ratio.

Thus this decrease of the ME/DE ratio, which was the only one significant change in the operated pigs, might be a non specific consequence of surgery.

Nevertheless, such an effect is difficult to explain. In the previous experiment (LAPLACE, 1976), we hypothetized that energy deposition in the adipose tissue was reduced. Some trends towards a reduced adiposity of the carcasses of pigs were recorded indeed 1 month after enterectomy (LAPLACE, 1973) and confirmed 4 months after enterectomy (LAPLACE, 1975), though this effect, significant in male and female pigs, always remained unsignificant in castrated male pigs. As the nitrogen losses in the urines and the nitrogen retention coefficient were never significantly modified, and as castrated male pigs were used in this experiment, this hypothesis must be definitively discarded.

An other explanation might involve a change of the composition of the non nitrogenous or even of the nitrogenous fraction of the urines, with a relative decrease of urea as compared to other compounds such as uric and hippuric acids, thus resulting in increased energy losses in the urines. But data concerning the final products of catabolism are not available to support further answer. Moreover it would be tempting to relate such changes to the post resectional compensatory hypertrophy, but the urinary losses of energy (as Kcal per $g$ nitrogen) are lower in resected pigs than in deafferented or in resected + deafferented ones. As compensatory hypertrophy is not elicited in deafferented pigs or fails to appear in resected + deafferented pigs (LAPLACE, 1980 a-1981), any relationship with post resectional hyperplasia seems to be unable to provide an explanation.

Whatever the reason for the decrease of the $\mathrm{ME} / \mathrm{DE}$ ratio, this effect must be provisionaly considered as a non specific consequence of surgery. Except for this small change, it may thus be concluded that, despite some disturbances of the gastric function (LAPLACE, $1980 \mathrm{~b}$ ), total deafferentation, performed alone or in combination with enterectomy, does not affect the digestive and metabolic utilization of food. 


\section{Acknowledgements}

To Daniel Bourdon from Station de Recherches sur l'Elevage des Porcs, for his careful management of animal experimentation.

\section{Résumé \\ Entérectomie, déafférentation vagale et bilan nutritionnel chez le porc}

Un bilan nutritionnel a été réalisé sur 36 porcs de race Large White pour mesurer l'utilisation digestive et métabolique des aliments, comparativement à celle enregistrée chez des porcs normaux non opérés, après l'une ou l'autre des interventions ci-après : déafférentation vagale totale, résection de $4 \mathrm{~m}$ de jéjunum distal, ou l'association déafférentation vagale et jéjunectomie partielle. L'essai conduit entre les dix-huitième et vingt-huitième jours post-opératoires montre l'absence de toute modification de l'utilisation digestive ou métabolique des aliments. Seule est enregistrée une réduction modeste mais significative de l'énergie métabolisable (exprimée en p. cent de l'énergie digestible). Cet effet s'avère cependant non spécifique puisque du même ordre de grandeur quelle que soit la nature de la ou des intervention (s) pratiquée (s).

\section{References}

Darcy B., Falempin M., Laplace J.P., Rousseau J.P., 1979. Importance de 1a voie vagale sensitive : Recherche d'une technique de déafférentation sélective chez le porc et le mouton. Ann. Biol, anim. Bioch. Biophys., 19, 881-888.

Henry Y., Rerat A., 1966. Utilisation des pommes de terre déshydratées et fraîches dans l'alimentation du porc en croissance, en comparaison avec l'orge. Ann. Zootech., 15, 231-251.

Laplace J.P., 1970. Résection intestinale chez le porc. 1) Observations préliminaires. Ann. Zootech., 19, 287-302.

LAPLACE J.P., 1973. Croissance corporelle et digestive et état d'adiposité chez le porcelet, un mois après résection limitée d'intestin grêle. Cah. Nutr. Diet., 8, 328-329.

LAPLACE J.P., 1975. Somatic and visceral growth, and adiposity in the pig after partial small bowel resection. Ann. Rech. Vet., 6, 265-288.

LAPLACE J.P., 1976. Résection intestinale chez le porc. 2) Bilans nutritionnels après résection limitée de jéjunum distal. Ann. Zootech., 25, 351-360.

LAPLACE J.P., 1980 a. Compensatory hypertrophy of the residual small intestine after partial enterectomy. A neuro humoral feed back? Ann. Rech. Vet., 11, 165-177.

LAPLACE J.P., 1980 b. Surgical deprivation of vagal afferences from the gastrointestinal tract of the pig : Clinical and E.M.G. studies, pp. 145-152. In Christensen J., Gastrointestinal motility, 1 vol., Raven Press, New York.

LAPLACE J.P., 1981. Impairment by vagal deafferentation of the compensatory hypertrophy after enterectomy, at high and low feeding levels. 2nd International Conference on intestinal adaptation, Titisee, may 24th-31th (in Press by M.T.P. Press, Lancaster).

Laplace J.P., Cuber J.C., Villiers P.A., 1979. Evacuation gastrique après déafférentation vagale subtotale chez le porc. Ann. Zootech., 28, 459-463. 